\title{
Review
}

\section{Oxidation catalysts prepared from biosorbents supported on zeolites}

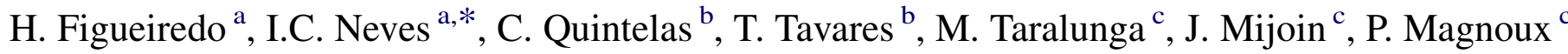 \\ ${ }^{\mathrm{a}}$ Departamento de Química, Universidade do Minho, Campus de Gualtar, 4710-057 Braga, Portugal \\ ${ }^{\mathrm{b}}$ Departamento de Engenharia Biológica, Universidade do Minho, Campus de Gualtar, 4710-057 Braga, Portugal \\ ${ }^{\mathrm{c}}$ Laboratoire de Catalyse en Chimie Organique, Université de Poitiers, UMR CNRS 6503, 40, Avenue du Recteur Pineau, F-86022 Poitiers Cedex, France \\ Received 16 January 2006; received in revised form 28 March 2006; accepted 3 April 2006 \\ Available online 12 May 2006
}

\begin{abstract}
The catalytic oxidation of 1,2-dichlorobenzene was investigated over $\mathrm{NaY}$ and $\mathrm{NaX}$ zeolites, loaded with chromium through the action of a robust biosorption system consisting of a bacterial biofilm supported on the zeolites. The results of biosorption showed that the maximum metal removal efficiency was $20 \%$, in both systems based on $\mathrm{NaY}$ or $\mathrm{NaX}$, starting from solutions with chromium(VI) concentrations ranging from 50 to $250 \mathrm{mg} \mathrm{Cr}_{\mathrm{r}} / \mathrm{L}$. The bacterial biofilm, Arthrobacter viscosus, supported on the zeolite reduces $\mathrm{Cr}$ (VI) to $\mathrm{Cr}(\mathrm{III})$. $\mathrm{The} \mathrm{Cr}(\mathrm{III})$ is retained in the zeolite by ion exchange. The new catalysts were characterized by spectroscopic methods (FTIR ), chemical analyses (ICP-AES), surface analysis (XRD) and thermal analysis (TGA). The various techniques of characterization show that this biosorption process does not modify the morphology and structure of the FAUzeolites. These catalysts, $\mathrm{Cr} / \mathrm{FAU}$, prepared through this new procedure present good activity and selectivity for dichlorobenzene oxidation in wet air at $350{ }^{\circ} \mathrm{C}$. The $\mathrm{Cr}_{50^{-}} \mathrm{Y}$ was selected as the most active, selective and stable catalyst for oxidation of 1,2-dichlorobenzene in wet air.
\end{abstract}

(C) 2006 Elsevier B.V. All rights reserved.

Keywords: Zeolites; Arthrobacter viscosus; Biosorbents; Cr/FAU; VOCs; Oxidation

\section{Contents}

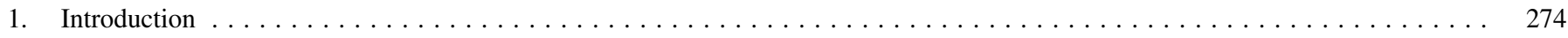

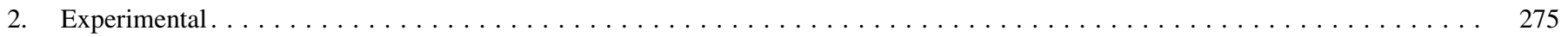

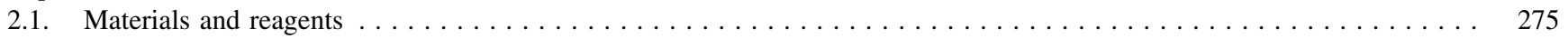

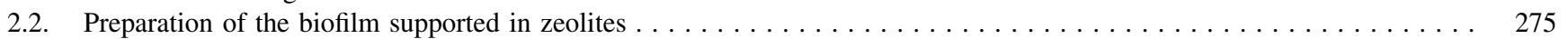

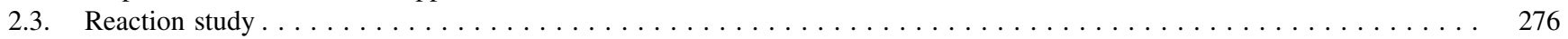

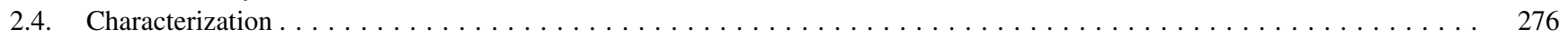

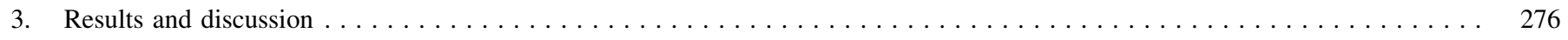

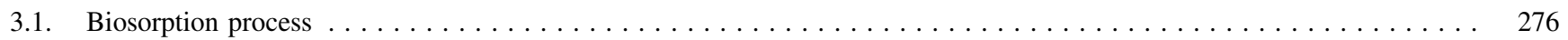

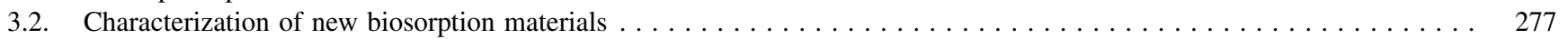

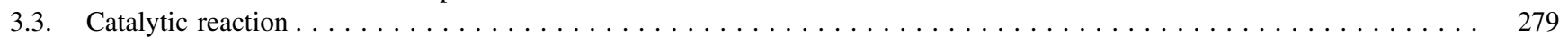

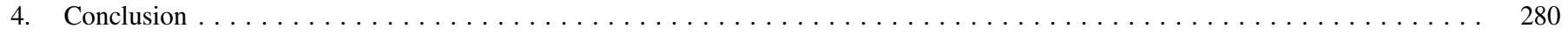

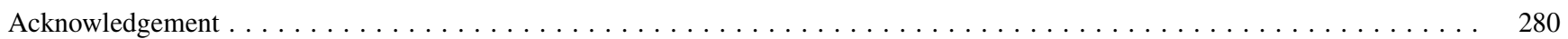

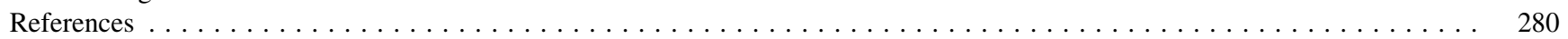

\section{Introduction}

Nowadays, pollution control is one of the major concerns for the scientific community as well as for environmentalists.

\footnotetext{
* Corresponding author. Tel.: +351 253604057x4410; fax: +351 253678983. E-mail address: ineves@quimica.uminho.pt (I.C. Neves).
}

The major pollutants are the greenhouse gases, metal, organic and inorganic effluents and volatile organic compounds (VOCs). Cadmium $(\mathrm{Cd})$, chromium $(\mathrm{Cr})$ and lead $(\mathrm{Pb})$ are common toxic pollutants in aqueous waste streams of many industries such as metal plating facilities, mining operations and tanneries. Contaminated soils pose a risk of metals groundwater and surface water contamination. Numerous processes exist for removing dissolved heavy metals including 
chemical precipitation, ion exchange, membrane filtration, reverse osmosis and carbon adsorption [1].

Activated carbon adsorption is considered to be a competitive and effective process for the removal of metals at trace quantities. However, the use of activated carbon is expensive for small industries with tight budget and they need alternative technologies or sorbents for these treatments $[2,3]$. In this regard, zeolites have a great potential for removing heavy metal from industrial wastewater. The existence of a net negative structural charge in the structure promotes a strong affinity for metal ions which gives good adsorption properties to these supports. Sodium, potassium and other positively charged exchangeable ions occupy the channels within the three-dimensional structure and can be replaced by heavy metals [4].

The applications of natural zeolites to wastewater treatment have been done in recent years. The removal of heavy metals from wastewater using clinoptilolite, the most abundant zeolite in nature, was studied. The results indicated that the ion exchange loading values could range from $1.6 \mathrm{mg} / \mathrm{g}$ for $\mathrm{Pb}^{2+}$ to $0 \mathrm{mg} / \mathrm{g}$ for $\mathrm{Cr}^{3+}$ [5]. One of the approaches to remove the $\mathrm{Cr}^{3+}$ from solution is to combine biosorption by a bacterium with ion exchange capacity of a zeolite.

Biosorption is the accumulation of metals by biological materials without active uptake and can be considered as a collective term for a number of passive accumulation processes which may include ion exchange, coordination, complexation, chelation, adsorption and microprecipitation [6]. Other authors [7] referred that biosorption is the ability of biological materials to accumulate heavy metals from waste streams by either metabolically mediation or by purely physio-chemical pathways of uptake.

Bacteria are quite adequate for heavy metals biosorption due to their ability to sorb metal ions, suitability for natural environments and low cost. Arthrobacter viscosus is a good exopolysaccharide producer, which, by itself, would allow foreseeing good qualities for support adhesion and for metal ions entrapment [8]. The new systems combine the biosorption properties of the microorganism with some characteristics of the heterogeneous catalysts, such as ion exchange properties and shape selectivity.

Among different heavy metals that may be removed from liquid solutions by biosorption, chromium demands special attention as it may present several oxidation states. Chromium was removed from $\mathrm{K}_{2} \mathrm{Cr}_{2} \mathrm{O}_{7}$ liquid solutions with different initial concentrations. A possible reduction of $\mathrm{Cr}_{2} \mathrm{O}_{7}{ }^{2-}$ may be performed by the biofilm itself. The metabolic reduction has been studied and modeled for different pure bacterial cultures [9]. A. viscosus bacterium supported on the zeolite reduces $\mathrm{Cr}(\mathrm{VI})$ to $\mathrm{Cr}$ (III) and the $\mathrm{Cr}$ (III) is retained in the zeolite by ion exchange. In this way, the bacteria allow metal loading of the zeolite, as sterical limitations and charge repulsions would not permit the zeolite loading with the anionic species, $\mathrm{Cr}_{2} \mathrm{O}_{7}{ }^{2-}$. This research adds two important approaches, biosorption of toxic pollutants and catalytic oxidation of halogenated benzene derivatives. What is usually considered a xenobiotic pollutant, chromium(VI) in wastewater can, therefore, be transformed in a competitive and selective catalyst to be applied in oxidation of persistent organic compounds.

Catalytic oxidation is one of the most promising technologies for the removal of organic compounds from waste gas (VOCs and POPs). In this context, dichlorobenzene is known to be an important precursor of PCDDs and PCDFs and was chosen as a suitable model compound for the catalyzed deep oxidation of chlorinated persistent organic pollutants (POPs). Catalytic oxidation of chlorinated aromatics is generally carried out over three main catalyst types: $\mathrm{TiO}_{2}$ based $\mathrm{V}_{2} \mathrm{O}_{5} /$ $\mathrm{WO}_{3}$ [10-16], noble metals ( $\mathrm{Pt}$ and $\mathrm{Pd}$ ) supported on various oxides [17-20] and zeolites [21-24]. According to recent studies, zeolites seem to be very promising towards oxidation of chlorinated compounds [25-27]. However, the cost of noble metals justifies their substitution by transition metals. In this case, the proposed solution takes advantage of the synergetic effect between the ability of the biological material, i.e. reducing the metallic ion, and the ion exchange performed by the zeolites.

This work presents the oxidation of 1,2-dichlorobenzene in wet air at $350{ }^{\circ} \mathrm{C}$ over the new $\mathrm{Cr} / \mathrm{FAU}$ catalysts. These novel catalyst samples were prepared from a robust biosorption system consisting of a bacterial biofilm supported on faujasite (FAU) zeolites. The $\mathrm{NaY}$ or $\mathrm{NaX}$ worked as a support for the biofilm and was mixed with an inoculated medium with $A$. viscosus bacterium, in batch experiments. The new biosorbents supported in the zeolite were tested in solutions with low concentration of chromium. Total metal ions concentrations were measured with an atomic absorption spectrophotometer (AAS). The results showed that the maximum removal efficiency was $20 \%$ for $\mathrm{Cr}$ in both systems based on $\mathrm{NaY}$ or $\mathrm{NaX}$, and the $A$. viscosus bacterium supported in zeolite reduces $\mathrm{Cr}(\mathrm{VI})$ to $\mathrm{Cr}(\mathrm{III})$.

\section{Experimental}

\subsection{Materials and reagents}

A. viscosus was obtained from the Spanish Type Culture Collection of the University of Valência. Aqueous chromium solutions were prepared by diluting $\mathrm{K}_{2} \mathrm{Cr}_{2} \mathrm{O}_{7}$ (Aldrich) in distillated water. The faujasite zeolites $\mathrm{NaY}(\mathrm{Si} / \mathrm{Al}=2.88)$ and $\mathrm{NaX}(\mathrm{Si} / \mathrm{Al}=1.63)$ with the specific surface area of $800 \mathrm{~m}^{2} \mathrm{~g}^{-1}$, were obtained from W.R. Grace. The zeolites were calcined at $500{ }^{\circ} \mathrm{C}$ during $8 \mathrm{~h}$ under a dry air stream prior to use.

\subsection{Preparation of the biofilm supported in zeolites}

The preparation of the biosorbents was carried out using the batch method and all experimental work was conducted in triplicate. For the microorganism growth a medium with $5 \mathrm{~g} / \mathrm{L}$ of peptone, $3 \mathrm{~g} / \mathrm{L}$ of malt extract, $3 \mathrm{~g} / \mathrm{L}$ of yeast extract and $10 \mathrm{~g} / \mathrm{L}$ of glucose was used, sterilized at $120{ }^{\circ} \mathrm{C}$ for $20 \mathrm{~min}$. Then, batch adsorption experiments were conducted using $1.0 \mathrm{~g}$ of the $\mathrm{Y}$ or $\mathrm{X}$ zeolites with $15 \mathrm{~mL}$ of $A$. viscosus culture media and $150 \mathrm{~mL}$ of the different dichromate solutions $(50,100,150$ 
and $250 \mathrm{mg}_{\mathrm{Cr}} / \mathrm{L}$ ) in $250 \mathrm{~mL}$ Erlenmeyer flasks. The Erlenmeyer flasks were kept at $28{ }^{\circ} \mathrm{C}$, with moderate stirring. Samples $(1 \mathrm{~mL})$ of the liquid phase were taken, centrifuged and analyzed for metals using atomic absorption spectrophotometry. The new samples obtained after biosorption studies were filtered off and washed with distilled water. The samples have been identified by designation $\mathrm{Cr}_{n}$ zeolites, where $n$ represents the initial concentrations of chromium solutions. Samples with $n=50$ $\left(50 \mathrm{mg}_{\mathrm{Cr}} / \mathrm{L}\right), 100\left(100 \mathrm{mg}_{\mathrm{Cr}} / \mathrm{L}\right), 150\left(150 \mathrm{mg}_{\mathrm{Cr}} / \mathrm{L}\right)$ and 250 $\left(250 \mathrm{mg}_{\mathrm{Cr}} / \mathrm{L}\right)$ were prepared with both supports. After washing, the $\mathrm{Cr}_{n}$ - $\mathrm{Y}$ and $\mathrm{Cr}_{n}-\mathrm{X}$ were calcined at $500{ }^{\circ} \mathrm{C}$ during $8 \mathrm{~h}$ under a dry air stream before the catalytic reaction in order to remove the organic matter of the A. viscosus bacterium. This heat treatment is essential to assure that the organic matter is completely burnt off and will not participate in the catalytic step and to allow the ion exchange between the zeolite and the residual $\mathrm{Cr}(\mathrm{III})$.

\subsection{Reaction study}

Catalytic activity tests were carried out in a fixed bed reactor (i.d. $=10 \mathrm{~mm}$ ), under atmospheric pressure and at $350{ }^{\circ} \mathrm{C}$ using $0.14 \mathrm{~g}$ of catalyst (grain size between 200 and $400 \mu \mathrm{m}$ ). Before reaction, catalyst samples were pre-treated in situ under dry airflow $\left(90 \mathrm{~mL} \mathrm{~min}^{-1}\right)$ at $350{ }^{\circ} \mathrm{C}$ for $6 \mathrm{~h}$, then cooled down to the reaction temperature. 1,2-Dichlorobenzene $\left(\mathrm{C}_{6} \mathrm{H}_{4} \mathrm{Cl}_{2}\right)$ was introduced into the reactor using a bubbling flask containing $\mathrm{C}_{6} \mathrm{H}_{4} \mathrm{Cl}_{2}$ swept by a dry air flow, leading to a gaseous mixture directed to a condenser maintained at $+15.2{ }^{\circ} \mathrm{C}$. The resulting effluent was then mixed with wet air to ensure that hygrometric level was matching industrial conditions. For the standard condition, the reactant mixture contained $1.03 \%$ of water (corresponding to a hygrometry of about 50\%) and $667 \mathrm{ppm}$ of

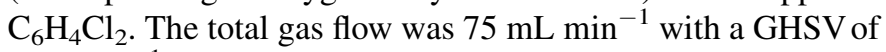
$18.000 \mathrm{~h}^{-1}$. The reaction products were analyzed using an online gas chromatograph, equipped with a FID detector and a VF-5ms column for the analysis of $\mathrm{C}_{6} \mathrm{H}_{4} \mathrm{Cl}_{2}$ and probable polychlorinated benzenes $\left(\mathrm{PhCl}_{3}\right)$ and with a TCD detector and a Porapak Q column for $\mathrm{CO}$ and $\mathrm{CO}_{2}$ analysis. The carbon balance, including the amount of carbon deposited on the catalyst at the end of reaction, was always higher than $98 \%$. Mass spectrometer (Thermo Finnigan Automass Multi) and specific Dräger tubes were used to detect the eventual $\mathrm{Cl}_{2}$ and hydrogen chloride production.

\subsection{Characterization}

Total metal ions concentrations used during the biosorption essays were measured using a Varian Spectra AA-400, an Atomic Absorption Spectrophotometer. Room temperature FTIR spectra of materials were obtained from powdered samples on $\mathrm{KBr}$ pellets, using a Bomem MB104 spectrometer in the range $4000-500 \mathrm{~cm}^{-1}$ by averaging 20 scans at a maximum resolution of $4 \mathrm{~cm}^{-1}$. X-ray diffraction patterns (XRD) were recorded using a Philips Analytical X-ray model PW1710 BASED diffractometer system. The solids samples were exposed to the $\mathrm{Cu} \mathrm{K} \alpha$ radiation at room temperature in a
$2 \theta$ range between $5^{\circ}$ and $70^{\circ}$. Thermogravimetric analyses (TGA) of samples were carried out using TGA 50 Shimadzu instrument under high purity helium supplied at a constant $50 \mathrm{~mL} \mathrm{~min}^{-1}$ flow rate. All samples were subjected to a $6{ }^{\circ} \mathrm{C} \min ^{-1}$ heating rate and were characterized between 25 and $550{ }^{\circ} \mathrm{C}$ on aluminum sample cell. The elemental chemical analyses ( $\mathrm{Si}, \mathrm{Al}, \mathrm{Na}$ and $\mathrm{Cr}$ ) were performed by University of Minho, Departamento de Ciências da Terra, using inductively coupled plasma atomic emission spectrometry (ICP-AES). C, $\mathrm{H}$ and $\mathrm{N}$ analyses were carried out on a Leco CHNS-932 analyzer.

\section{Results and discussion}

\subsection{Biosorption process}

The fixation of chromium by a biofilm of $A$. viscosus supported on $\mathrm{NaY}$ and $\mathrm{NaX}$ zeolites varying the initial metal solutions concentration from 50 to $250 \mathrm{mg}_{\mathrm{Cr}} / \mathrm{L}$ is described in Fig. 1. These graphs show the residual chromium concentration in solution as a function of contact time. In steady-state conditions, no difference between the two supports is detected and the maximum removal efficiency was $20 \%$ for chromium in both systems.

The removal of chromium in both systems was fast and presented a typical and well known biosorption kinetics [8], which includes two phases: the first one, very fast and not
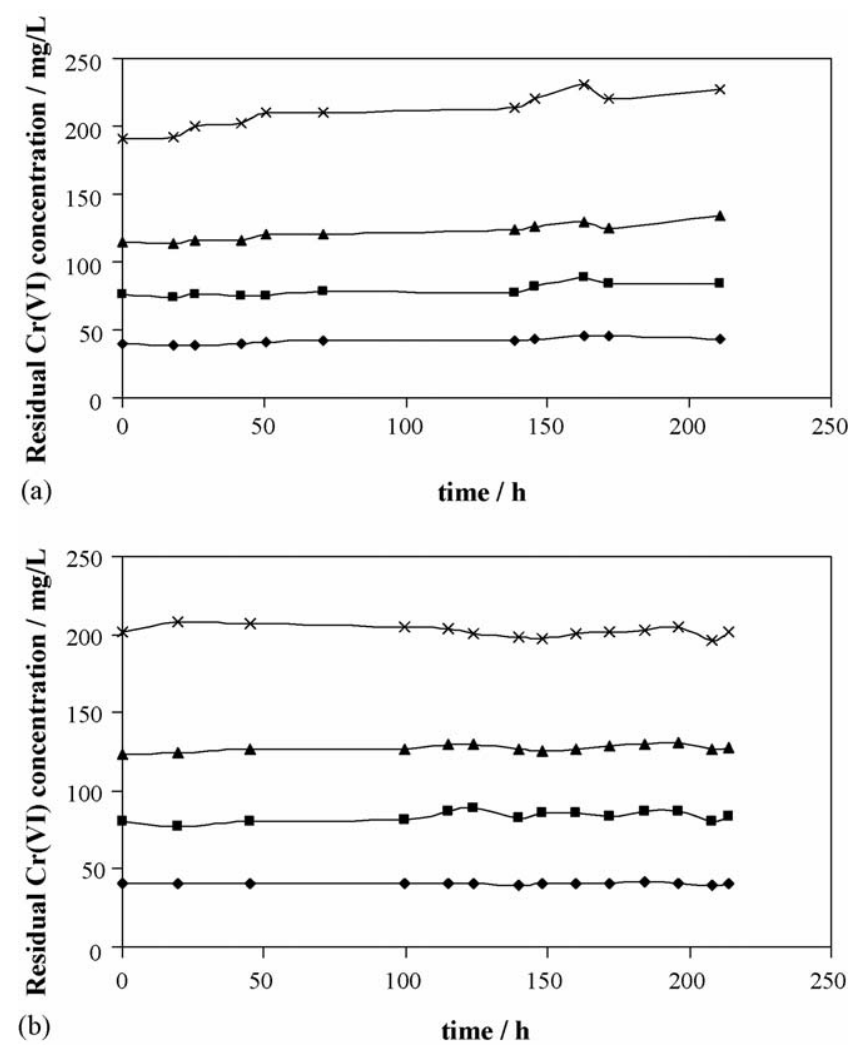

Fig. 1. Residual chromium concentration in solution after biosorption by $A$. viscosus supported on (a) $\mathrm{Y}$ and (b) $\mathrm{X}$ zeolites for different initial chromium concentration and as a function of contact time: (x) $250 \mathrm{mg}_{\mathrm{Cr}} / \mathrm{L},(\boldsymbol{\Delta}) 150 \mathrm{mg}_{\mathrm{Cr}} /$ $\mathrm{L},(\boldsymbol{\square}) 100 \mathrm{mg}_{\mathrm{Cr}} / \mathrm{L}$ and $(\diamond) 50 \mathrm{mg}_{\mathrm{Cr}} / \mathrm{L}$. 


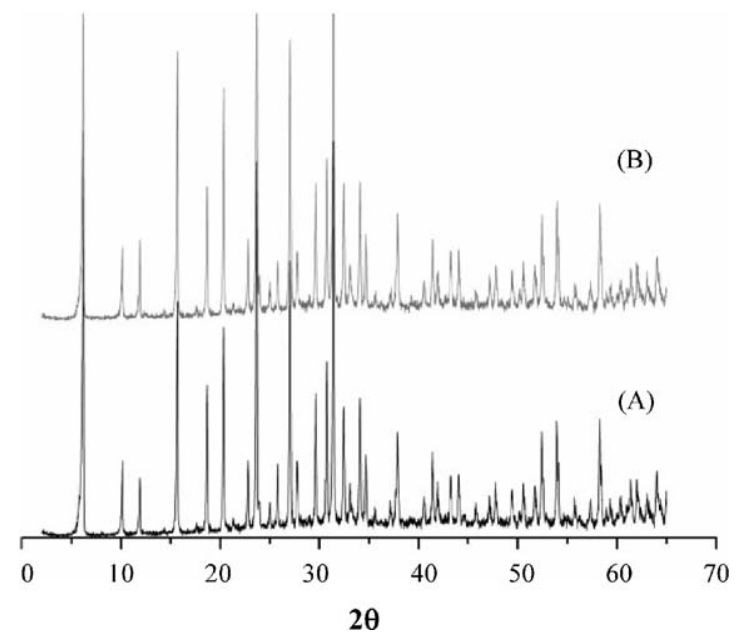

Fig. 2. XRD diffraction patterns of $\mathrm{NaY}(\mathrm{A})$ and $\mathrm{Cr}_{100}-\mathrm{Y}$ after calcination (B).

observable in Fig. 1, but determined by mass balance, is associated with the external cell surface, biosorption itself, and the second one is an intra-cellular accumulation/reaction, depending on the cellular metabolism [28]. Consequently, the ageing of the biofilm is responsible for a small increase in concentration of chromium in solution, observable in Fig. 1a. The relatively low maximum removal efficiency seems to be connected with the apparent lack of affinity between the anionic charge of the metal ion and the anionic charge of the bacteria and with the high ionic radius of the chromium ion.

The peculiar adsorptive properties of zeolites are originated from the negative charge of the framework $\mathrm{Al}$ atoms, which are located inside the three-dimensional pore structure of the solid. Although the zeolites exhibit large specific surfaces areas, typically higher than $300 \mathrm{~m}^{2} \mathrm{~g}^{-1}$, most of this area is internal with an internal void volume above $0.1 \mathrm{~cm}^{3} \mathrm{~g}^{-1}$ [29]. These limitations probably reduce the adhesion of the A. viscosus bacterium to the support, as the characteristic dimension of bacteria ranges from 1 to $10 \mu \mathrm{m}$. However, the role of the biofilm is the reduction of the anionic species to a smaller cation, $\mathrm{Cr}(\mathrm{III})$, and this ion is easily ion exchanged on the internal surface of the zeolite. The reduction can only occur on the outer surface of the zeolite as $\mathrm{Cr}_{2} \mathrm{O}_{7}^{2-}$ is not able to get inner the zeolite framework.

\subsection{Characterization of new biosorption materials}

The solid samples obtained after biosorption process were characterized by surface analysis (XRD), chemical analyses (ICP-AES), spectroscopic methods (FTIR) and thermal analysis (TGA).
Powder X-ray diffraction patterns of $\mathrm{NaY}$ or $\mathrm{NaX}$ and $\mathrm{Cr}_{n}-\mathrm{Y}$ and $\mathrm{Cr}_{n}-\mathrm{X}$ were recorded at $2 \theta$ values between $5^{\circ}$ and $70^{\circ}$. The XRD patterns of parents FAU zeolites and the modified zeolites with chromium are very similar and the sample $\mathrm{Cr}_{100^{-}} \mathrm{Y}$ after calcination has been chosen as an example. In Fig. 2 is depicted the XRD diffraction of $\mathrm{NaY}(\mathrm{A})$ and $\mathrm{Cr}_{100^{-}} \mathrm{Y}(\mathrm{B})$.

XRD diffraction patterns confirm that there is no loss in FAU-zeolites crystallinity after the biosorption process. No variation was observed in the zeolite lattice parameters after the biosorption process. Peaks due to chromium in both systems were not detected, probably because of its very low percent loading.

Chemical analyses were also carried out on the solid $\mathrm{Cr}_{n}$ FAU samples. The molar Si/Al ratio, the weight percentage of $\mathrm{Cr}$ (III) loadings and the estimated number of chromium ions per unit cell obtained by bulk chemical analysis are presented in Table 1. For both faujasite zeolites, the difference in the $\mathrm{Si} / \mathrm{Al}$ ratio between $\mathrm{NaY}$ and $\mathrm{NaX}$ is due to the higher $\mathrm{Al}$ content in $\mathrm{NaX}$. The increase of the number of charge-compensating cations or number of $\mathrm{Na}$ must be responsible for the higher amount of chromium in $\mathrm{NaX}$ after the biosorption process. The $\mathrm{Si} / \mathrm{Al}$ ratio did not change substantially upon $\mathrm{Cr}$ (III) exchange for increasing chromium concentration stages (Table 1), which indicates that during the biosorption processes no dealumination or modification of the structure of the FAU-zeolites occurred, in agreement with XRD analysis.

The number of chromium ions per unit cell determined from the amount of chromium taken up by the zeolites after the biosorption processes (Table 1) as function of the different initial concentrations of chromium solutions is presented in Fig. 3. Both systems are able to remove low amounts of chromium. For both systems, only the samples with $50 \mathrm{mg}_{\mathrm{Cr}} / \mathrm{L}$ $\left(\mathrm{Cr}_{50^{-}} \mathrm{X}\right.$ and $\left.\mathrm{Cr}_{50^{-}} \mathrm{Y}\right)$ have the same amount of chromium removed (Table 1). However, when the chromium concentration solution increases, the system based on $\mathrm{NaX}$ is more efficient in removing chromium from aqueous solution. The maximum metal removal efficiency is $20 \%$, for both supports, as a consequence of the biofilm action, but the relative $\mathrm{Cr}$ (III) enrichment detected for the $\mathrm{NaX}$ in comparison with the $\mathrm{NaY}$, results from the major loading of this last one in $\mathrm{Na}$ exchangeable ions.

Structural information of $\mathrm{Cr}_{n}-\mathrm{Y}$ and $\mathrm{Cr}_{n}-\mathrm{X}$ after biosorption process has been obtained by FTIR spectroscopy. It was found that the FTIR patterns of parents FAU zeolites and $\mathrm{Cr}_{n}$-FAU samples were very similar and the sample $\mathrm{Cr}_{100}-\mathrm{Y}$ has been chosen as an example. The FTIR spectra in the range 4000$500 \mathrm{~cm}^{-1}$ are presented in Fig. 4a for the parent NaY (A), A. viscosus bacterium (B), NaY with A. viscosus bacterium (C)

Table 1

Chemical analysis of the zeolite samples after biosorption process

\begin{tabular}{lllllllllll}
\hline & $\mathrm{NaY}$ & $\mathrm{Cr}_{50}-\mathrm{Y}$ & $\mathrm{Cr}_{100}-\mathrm{Y}$ & $\mathrm{Cr}_{150}-\mathrm{Y}$ & $\mathrm{Cr}_{250}-\mathrm{Y}$ & $\mathrm{NaX}$ & $\mathrm{Cr}_{50}-\mathrm{X}$ & $\mathrm{Cr}_{100}-\mathrm{X}$ & $\mathrm{Cr}_{150}-\mathrm{X}$ & $\mathrm{Cr}_{250}-\mathrm{X}$ \\
\hline $\mathrm{Si} / \mathrm{Al}$ & 2.88 & 2.95 & 2.93 & 2.95 & 2.94 & 1.63 & 1.63 & 1.62 & 1.63 \\
$\mathrm{Cr}$ & - & 0.11 & 0.14 & 0.15 & 0.22 & - & 0.08 & 0.19 & 0.23 \\
$\mathrm{Cr}^{\text {III }} / \mathrm{UC}^{\mathrm{b}}$ & - & 0.35 & 0.45 & 0.48 & 0.70 & - & 0.28 & 0.67 & 0.80 & 1.63 \\
\hline
\end{tabular}

${ }^{\mathrm{a}}$ Chromium(III) loading on FAU-zeolites (wt \%) after biosorption process.

${ }^{\mathrm{b}}$ Number of chromium ions per unit cell determined from the $\mathrm{Cr}(\mathrm{III})$ loading on FAU-zeolites after biosorption process. 


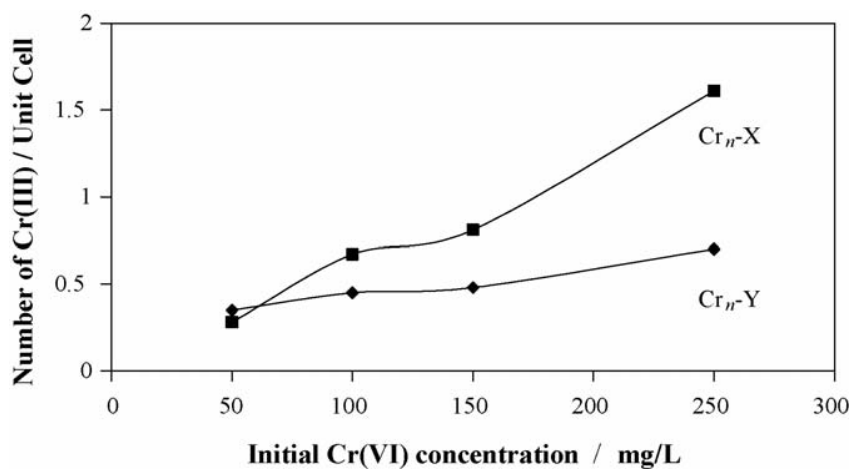

Fig. 3. Number of chromium ions per unit cell determined from the amount of chromium-exchanged in zeolites by a biofilm of $A$. viscosus supported on $(\bullet) \mathrm{Y}$ and (ם) X zeolites for different initial concentrations of chromium solutions.

and $\mathrm{Cr}_{100^{-}} \mathrm{Y}$ after calcination (D). Fig. 4b shows the parent $\mathrm{NaY}$ (A), NaY with A. viscosus bacterium (B), $\mathrm{Cr}_{100}-\mathrm{Y}$ before (C) and after (D) calcination for the range $2000-800 \mathrm{~cm}^{-1}$.

In systems with $\mathrm{Y}$ and $\mathrm{X}$ zeolites, the spectra of the parent zeolites and modified zeolites are dominated by strong zeolite bands: the broad band at $3700-3300 \mathrm{~cm}^{-1}$ is attributed to surface hydroxyl groups and bands corresponding to the lattice

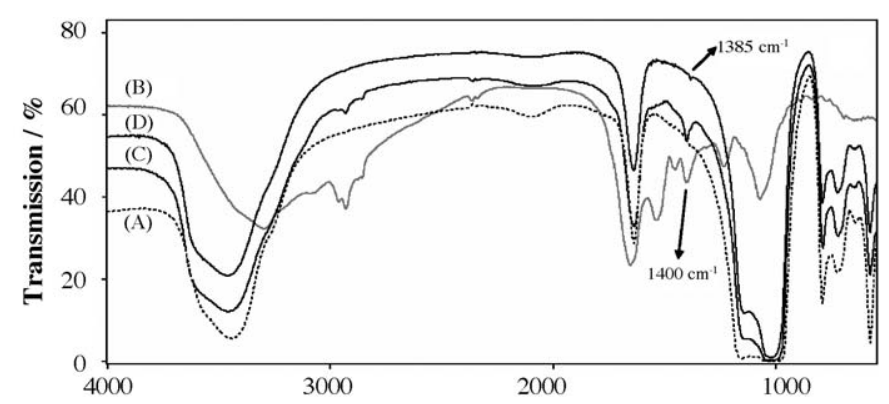

(a)

Wavenumber $/ \mathbf{c m}^{-1}$

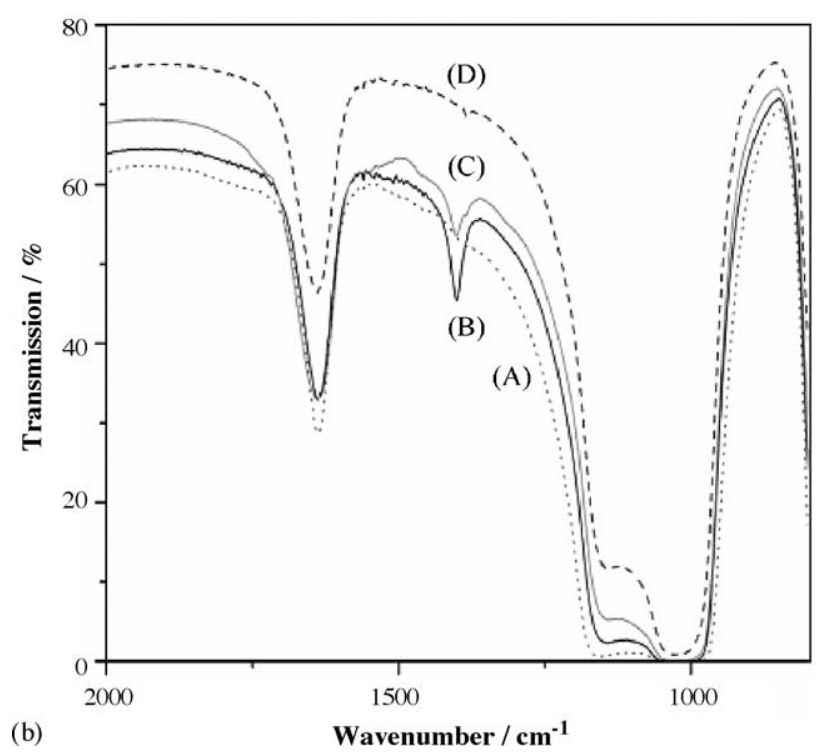

Fig. 4. (a) FTIR spectra in the range $4000-500 \mathrm{~cm}^{-1}$ for: $\mathrm{NaY}$ (A), A. viscosus bacterium (B), NaY with $A$. viscosus bacterium (C) and $\mathrm{Cr}_{100}-\mathrm{Y}$ after calcination (D). (b) FTIR spectra in the range $800-2000 \mathrm{~cm}^{-1}$ for: $\mathrm{NaY}$ (A), NaY with A. viscosus bacterium (B), $\mathrm{Cr}_{100}-\mathrm{Y}$ before (C) and after (D) calcination. vibrations are observed in the spectral region between 1300 and $450 \mathrm{~cm}^{-1}$ [30]. No shift or broadening of these FAU zeolites vibrations are observed upon inclusion of chromium by the biosorption process, which provides further evidence that the framework zeolite remains unchanged.

In order to confirm the presence of the A. viscosus bacterium in both FAU systems, the zeolites were mixed in the same experimental conditions with $15 \mathrm{~mL}$ of $A$. viscosus culture media and after analyzed by FTIR. The infrared spectrum of the A. viscosus bacterium (Fig. 4a-spectrum B) is typical from bacterial extracellular polymeric substances with a complex mixture of macromolecular polyelectrolytes including polysacharides, proteins, nucleic acids [31] and lipids or humic substances [32]. The FTIR spectrum shows one broad band in $3300 \mathrm{~cm}^{-1}$ due to the vibrations of hydroxyl and amide $(\mathrm{N}-\mathrm{H}$ stretching) groups; the small bands in the range between 2970 and $2800 \mathrm{~cm}^{-1}$ are attributed to $\mathrm{C}-\mathrm{H}$ stretching of the groups $\mathrm{CH}_{2}$ and $\mathrm{CH}_{3}$; the characteristic region of the bands between 1650 and $1400 \mathrm{~cm}^{-1}$ are attributed to the vibrations of the functional groups such as carboxyl, phosphoric, amine and the bands in the frequency range $1250-900 \mathrm{~cm}^{-1}$ result from vibrations of the polysaccharides from the bacterium [31-33]. In the NaY with A. viscosus bacterium spectrum (Fig. 4aspectrum C), the presence of the organic material can be only detected by small bands at 2970, 2925 and $2860 \mathrm{~cm}^{-1}$, and at 1457 and $1400 \mathrm{~cm}^{-1}$, where the zeolite does not absorb.

The IR spectra of the modified $\mathrm{Cr}_{100}-\mathrm{Y}$ before calcination exhibits a band at $1400 \mathrm{~cm}^{-1}$ attributed to the presence of organic matter from the $A$. viscosus bacterium and a slight band at $1385 \mathrm{~cm}^{-1}$ which is assigned to the presence of chromium after the biosorption process (Fig. $4 \mathrm{~b}$-spectrum C). After the calcination, (Fig. 4a and b-spectrum D) the absence of the bands in the region $2970-2800 \mathrm{~cm}^{-1}$ and of the band at $1400 \mathrm{~cm}^{-1}$ is evidence for the previous presence of the $A$. viscosus.

The success of the heat treatment of the samples in both systems, to assure that the organic matter is completely burnt off, was confirmed by the analytical data of carbon and nitrogen obtained by elemental analysis. As expected, it was not detected the presence of carbon and nitrogen in any sample.

Complementary studies using thermal analysis contributed to a better understanding of the effect of the A. viscosus bacterium and of the concentration of $\mathrm{Cr}$ (III) on the thermal properties of framework zeolite. The TGA curves of parent FAU zeolites and of $\mathrm{Cr}_{n}$-FAU samples were very similar and sample $\mathrm{Cr}_{250}-\mathrm{X}$ has been chosen as an example. Fig. 5 shows the TGA curve with weight loss derivative behaviour of the parent $\mathrm{NaX}$ zeolite and of $\mathrm{Cr}_{250}-\mathrm{X}$.

The TGA curve for the parent zeolite shows a weight loss at $120{ }^{\circ} \mathrm{C}$ which can be attributed to the removal of intra-zeolite water. After the biosorption process, two major stages of weight loss can be evidenced in a broad temperature range (i.e. 100$500{ }^{\circ} \mathrm{C}$ ). The first stage occurs above $130{ }^{\circ} \mathrm{C}$ with comparable weight losses for all samples and it is most likely due to intrazeolite water desorption. On the other hand, differences were observed at higher temperatures in the second stage of the TGA curves, which corresponds to the decomposition of the organic 


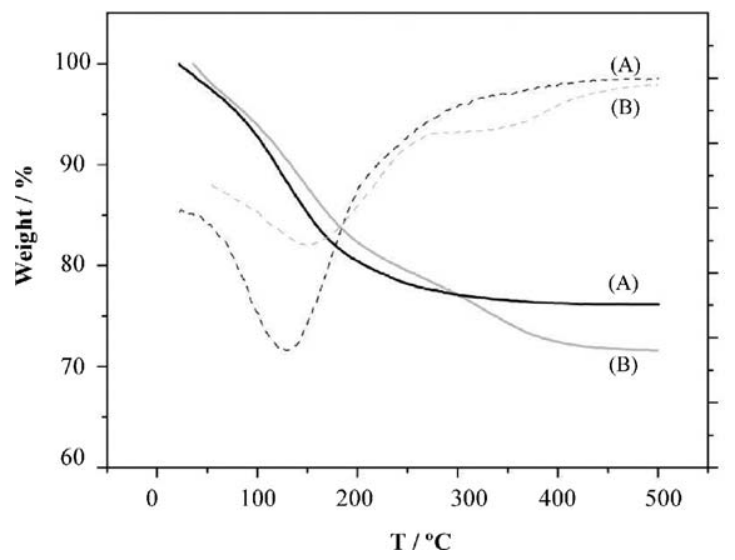

Fig. 5. TG (-) and DTG (- - ) curves for $\mathrm{NaX}(\mathrm{A})$ and $\mathrm{Cr}_{250}-\mathrm{X}(\mathrm{B})$.

matter of the A. viscosus bacterium, in the onset temperature of the decomposition process, as well as in the weight loss extent. Results are summarized in Table 2.

Differences in weight losses and onset temperatures of organic matter of the A. viscosus bacterium decomposition in both systems are most probably related to the different ratio of $\mathrm{Si} / \mathrm{Al}$ between the zeolites. In fact, the X-zeolites have an increase in the charge-compensating cations due to higher $\mathrm{Na}$ number which promote the efficiency of bacterium adhesion. After calcination, the TGA curves of $\mathrm{Cr}_{n}$-FAU are very similar with parent zeolites.

\subsection{Catalytic reaction}

The catalytic oxidation of 1,2-dichlorobenzene (1,2- $\left.\mathrm{PhCl}_{2}\right)$ was carried out at $350{ }^{\circ} \mathrm{C}$ over $\mathrm{NaY}$ and $\mathrm{Cr}_{50^{-}} \mathrm{Y}$, as well as over $\mathrm{NaX}, \mathrm{Cr}_{50}-\mathrm{X}$ and $\mathrm{Cr}_{100^{-}} \mathrm{X}$ samples. This study was achieved particularly over $\mathrm{Cr}_{50}$-FAU because these samples present approximately the same quantity of chromium per unit cell (Fig. 3). The total conversion of $1,2-\mathrm{PhCl}_{2}$ and conversion into $\mathrm{CO}_{2}$ over these two catalysts were reported in Fig. 6, as a function of reaction time.

Table 3 presents the catalytic behaviour of tested samples. Whereas $\mathrm{NaY}$ and $\mathrm{Cr}_{50^{-}} \mathrm{Y}$ are stable throughout the reaction, $\mathrm{NaX}$ and $\mathrm{Cr}-\mathrm{X}$ deactivate as the function of time. Global conversion over $\mathrm{Cr}_{50} \mathrm{X}$ decreases from $60 \%$ after $5 \mathrm{~min}$ reaction to $35.5 \%$ after $4 \mathrm{~h}$. Residual activity $\left(A_{\mathrm{R}}\right)$, taken as the ratio of final to initial conversion, ranges from 0.46 to 0.59 for $\mathrm{NaX}$ and $\mathrm{Cr}-\mathrm{X}$ catalysts, against near 1 for $\mathrm{NaY}$ and $\mathrm{Cr}_{50^{-}} \mathrm{Y}$ samples. This strong deactivation observed over $\mathrm{NaX}$ and $\mathrm{Cr}-\mathrm{X}$ catalysts can be due to the presence of $\mathrm{Na}^{+}$cations in sites III of
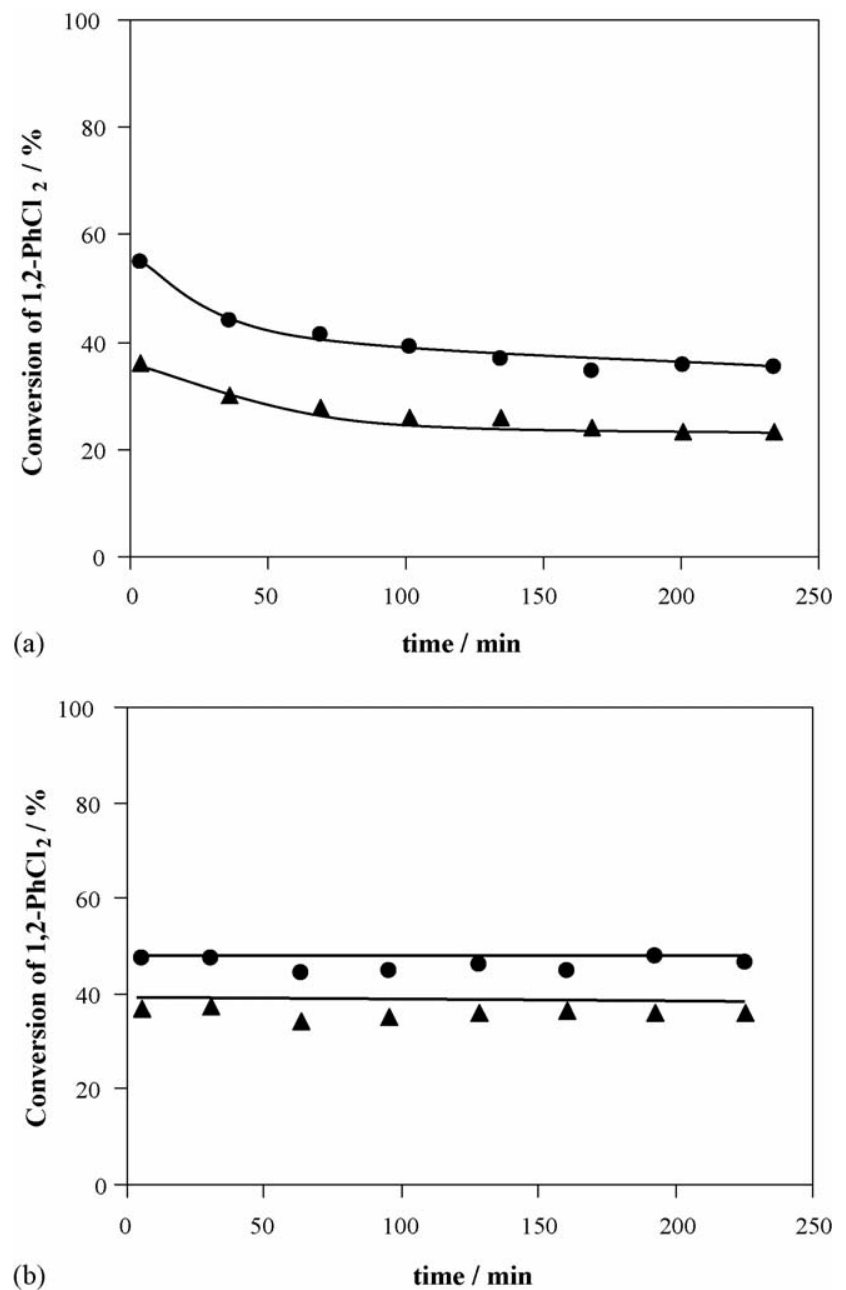

Fig. 6. Total conversion of 1,2-dichlorobenzene (๑) and conversion into $\mathrm{CO}_{2}$ $(\boldsymbol{\Delta})$ as a function of reaction time over $\mathrm{Cr}_{50} \mathrm{X}$ (a) and $\mathrm{Cr}_{50^{-}} \mathrm{Y}(\mathrm{b})\left(T=350{ }^{\circ} \mathrm{C}\right)$.

FAU zeolite, which can be removed into $\mathrm{NaCl}$ clusters. As in the case of dichloromethane degradation [26], the loss of part of sodium cations are substituted by protonic sites. Thus, after $4 \mathrm{~h}$ reaction $\mathrm{NaX}$ was as active as $\mathrm{NaY}$ for global degradation of 1,2- $\mathrm{PhCl}_{2}$. However, after the same period of time, the activity in oxidation (conversion into $\mathrm{CO}_{2}$ ) was slightly greater over $\mathrm{NaY}$ (and $\mathrm{Cr}-\mathrm{Y}) . \mathrm{CO}_{2}$ and $\mathrm{CO}(+\mathrm{HCl})$ were the main products formed during the reaction, no polychlorinated benzenes $\left(\mathrm{PhCl}_{3}\right)$ and no $\mathrm{Cl}_{2}$ were detected and coke formation was residual. Selectivity towards $\mathrm{CO}_{2}$ was better over $\mathrm{Cr}_{50}$-Y: near $80 \%$ against $67 \%$ over $\mathrm{Cr}_{50}$-X catalyst (Table 3 ). The effect of $\mathrm{Cr}$ content was also studied over FAU-X zeolites and it was

Table 2

Thermogravimetric analysis results of the zeolite samples after biosorption process

\begin{tabular}{lccccccccc}
\hline & $\mathrm{NaY} / \mathrm{NaX}$ & $\mathrm{Cr}_{50}-\mathrm{Y}$ & $\mathrm{Cr}_{100}-\mathrm{Y}$ & $\mathrm{Cr}_{150}-\mathrm{Y}$ & $\mathrm{Cr}_{250}-\mathrm{Y}$ & $\mathrm{Cr}_{50}-\mathrm{X}$ & $\mathrm{Cr}_{100}-\mathrm{X}$ & $\mathrm{Cr}_{150}-\mathrm{X}$ & $\mathrm{Cr}_{250}-\mathrm{X}$ \\
\hline$T_{1}{ }^{\mathrm{a}}\left({ }^{\circ} \mathrm{C}\right)$ & 120 & 130 & 120 & 120 & 120 & 130 & 130 & 130 & 130 \\
$T_{2}{ }^{\mathrm{b}}\left({ }^{\circ} \mathrm{C}\right)$ & - & 345 & 335 & 335 & 335 & 325 & 320 & 320 \\
Weight $\operatorname{loss}^{\mathrm{c}}(\%)$ & - & 3.2 & 3.5 & 4.0 & 4.8 & 4.7 & 6.1 & 7.7 & 7.6 \\
\hline
\end{tabular}

${ }^{\mathrm{a}}$ Temperature of water desorption obtained from DTG curve.

b Temperature of organic matter decomposition obtained from DTG curve.

c Weight loss due to organic matter decomposition obtained from DTG curve. 
Table 3

1,2- $\mathrm{PhCl}_{2}$ total conversion and conversion into $\mathrm{CO}_{2}$; selectivity into $\mathrm{CO}_{2}\left(S_{\mathrm{CO}}\right)$ taken after $5 \mathrm{~min}$ and $4 \mathrm{~h}$ reaction at $350{ }^{\circ} \mathrm{C}$ over $\mathrm{Cr}_{50}-\mathrm{Y}, \mathrm{Cr}_{50}-\mathrm{X}$ and $\mathrm{Cr}_{100}-\mathrm{X}$ catalysts; residual activity $\left(A_{\mathrm{R}}=\right.$ initial to final conversion ratio)

\begin{tabular}{|c|c|c|c|c|c|c|c|}
\hline \multirow[t]{3}{*}{ Catalysts } & \multicolumn{4}{|c|}{$1,2-\mathrm{PhCl}_{2}$ conversion $(\%)$} & \multirow[t]{3}{*}{$A_{\mathrm{R}\left(\mathrm{CO}_{2}\right)}$} & \multicolumn{2}{|c|}{$S_{\mathrm{CO}}(\%)$} \\
\hline & \multicolumn{2}{|l|}{ Total } & \multicolumn{2}{|l|}{$\mathrm{CO}_{2}$} & & \multirow[t]{2}{*}{$5 \mathrm{~min}$} & \multirow[t]{2}{*}{$4 \mathrm{~h}$} \\
\hline & $5 \mathrm{~min}$ & $4 \mathrm{~h}$ & $5 \mathrm{~min}$ & $4 \mathrm{~h}$ & & & \\
\hline $\mathrm{NaY}$ & 32.0 & 30.0 & 24.0 & 22.0 & 0.92 & 75 & 73 \\
\hline $\mathrm{Cr}_{50}-\mathrm{Y}$ & 47.5 & 47 & 37.5 & 37 & 0.99 & 79 & 79 \\
\hline $\mathrm{NaX}$ & 55.0 & 30.5 & 33.0 & 15.3 & 0.46 & 60 & 50 \\
\hline $\mathrm{Cr}_{50}-\mathrm{X}$ & 60.0 & 35.5 & 40.0 & 23.5 & 0.59 & 67 & 66 \\
\hline $\mathrm{Cr}_{100}-\mathrm{X}$ & 99.5 & 38.5 & 93.0 & 34.5 & 0.38 & 93.5 & 89.5 \\
\hline
\end{tabular}

concluded that the increase of $\mathrm{Cr}$ content increases the initial conversion $\left(\mathrm{Cr}_{50}\right.$ and $\mathrm{Cr}_{100}$ in Table 3$)$, but does not reduce the deactivation effect. This suggests that deactivation was well due to the loss of $\mathrm{Na}$ cations in exchange positions. However, the increase of $\mathrm{Cr}$ content leads to a better selectivity into $\mathrm{CO}_{2}$, even after deactivation. After $4 \mathrm{~h}$ reaction, production of $\mathrm{CO}_{2}$ is 1.5 times higher on $\mathrm{Cr}_{100}-\mathrm{X}$ than over $\mathrm{Cr}_{50}-\mathrm{X}$ and selectivity in $\mathrm{CO}_{2}$ was close to $90 \%$.

\section{Conclusion}

The results reported in this paper show that a biofilm of $A$. viscosus supported on $\mathrm{Y}$ and $\mathrm{X}$ zeolites is able to remove chromium from dilute solutions and can be applied in wastewater remediation. The reduction of $\mathrm{Cr}$ (VI) to $\mathrm{Cr}$ (III) is performed by the biofilm itself and this metal is exchanged in the zeolite. From physico-chemical studies presented, is clear evidence that biosorption process can use with zeolites without damage to the original matrix or loss of its crystallinity. These novel materials show good properties for catalytic oxidation of 1,2-dichlorobenzene in wet air. Among tested materials, $\mathrm{Cr}_{50}$-Y showed to be stable during $4 \mathrm{~h}$ reaction and able to convert about $50 \%$ of dichlorobenzene.

\section{Acknowledgements}

We thank Dr. A.S. Azevedo for collecting the powder diffraction data and Dr. C. Ribeiro, from Departamento de Ciências da Terra of Universidade do Minho, for chemical analysis. This work was supported by Fundação para a Ciência e Tecnologia (FCT-Portugal), under programme POCTI/ FEDER (POCTI/44840/QUI/2002). M. Taralunga gratefully acknowledges the Agence de l'Environnement et de la Maîtrise de l'Energie (ADEME) and the Région Poitou-Charentes for a scholarship.

\section{References}

[1] S.E. Bailey, T.J. Olin, R.M. Bricka, D.D. Adrian, Water Res. 33 (11) (1999) 2469.

[2] E. Erdem, N. Karapinar, R. Donat, J. Colloid Interface Sci. 280 (2004) 309.

[3] S.K. Pitcher, R.C.T. Slades, N.I. Ward, Sci. Total Environ. 334-335 (2004) 161.

[4] A. Corma, H. Garcia, Eur. J. Inorg. Chem. (2004) 1143.

[5] S. Babel, T.A. Kurniawan, J. Hazard. Mater. B97 (2003) 219.

[6] J.R. Duncan, D. Brady, A. Stoll, Environ. Technol. 15 (1994) 429.

[7] J.T. Matheickal, Q. Yu, G.M. Woodburn, Water Res. 33 (2) (1999) 335.

[8] C. Quintelas, T. Tavares, Biotecnol. Lett. 23 (2001) 1349.

[9] Y.T. Wang, H. Shen, Water Res. 31 (4) (1997) 727.

[10] L. Jin, M.A. Abraham, Ind. Eng. Chem. Res. 30 (1991) 89.

[11] S. Krishnamoorthy, J.P. Baker, M.D. Amiridis, Catal. Today 40 (1998) 39.

[12] H. Hagenmaier, K.H. Tichaczec, H. Brunner, G. Mittelbach, Organohalogen Compd. 3 (1990) 65.

[13] M. Stoll, J. Furrer, H. Seifert, G. Schaub, D. Unruh, Waste Manage. 21 (2001) 457.

[14] Y. Ide, K. Kashiwabara, S. Okada, T. Mori, M. Hara, Chemosphere 32 (1996) 189.

[15] R. Weber, T. Sakurai, Appl. Catal. B Environ. 34 (2001) 113.

[16] S. Lomnicki, J. Lichtenberger, Z. Xu, M. Waters, J. Kosman, M.D. Amiridis, Appl. Catal. B Environ. 46 (2003) 105.

[17] R.W. van den Brink, R. Louw, P. Mulder, Appl. Catal. B Environ. 16 (1998) 219.

[18] R.W. van den Brink, P. Mulder, R. Louw, Catal. Today 54 (1999) 101.

[19] R.W. van den Brink, M. Krzan, M.M.R. Feijen-Jeurissen, R. Louw, P. Mulder, Appl. Catal. B Environ. 24 (2000) 255.

[20] R.W. van den Brink, R. Louw, P. Mulder, Appl. Catal. B Environ. 25 (2000) 229.

[21] L. Becker, H. Förster, J. Catal. 170 (1997) 200.

[22] S. Sciré, S. Minico, C. Crisafulli, Appl. Catal. B Environ. 45 (2003) 234.

[23] S. Scire, S. Minico, C. Crissafulli, G. Burgio, V. Giuffrida, Stud. Surf. Sci. Catal. 142 (2002) 1023.

[24] S. Sciré, S. Minico, Catal. Lett. 91 (3-4) (2003) 199.

[25] L. Pinard, J. Mijoin, P. Magnoux, M. Guisnet, J. Catal. 215 (2003) 234.

[26] L. Pinard, P. Magnoux, P. Ayrault, M. Guisnet, J. Catal. 221 (2004) 662.

[27] L. Pinard, J. Mijoin, P. Ayrault, C. Canaff, P. Magnoux, Appl. Catal. B Environ. 51 (2004) 1.

[28] M.T. Tavares, C. Martins, P. Neto, in: A.K. Sengupta (Ed.), Hazardous and Industrial Wastes, Tecnomics Publishing Co., Lancaster, 1995, p. 223.

[29] A. Corma, Chem. Rev. 95 (1995) 559.

[30] B. Imelik, J.C. Vedrine (Eds.), Catalyst Characterization, Plenum Press, New York, 1994.

[31] A. Omoike, J. Chorover, Biomacromolecules 5 (2004) 1219.

[32] M.H. Zandvoort, P.N.L. Lens, E. Van Hullebusch, Soil Sediment Contam. 12 (5) (2003) 679.

[33] T. Udelhoven, D. Naumann, D. Schmitt, J. Appl. Spectrosc. 54 (2000) 1471. 